\title{
Women in Philosophy: Problems with the Discrimination Hypothesis
}

\author{
Neven Sesardic • Rafael De Clercq
}

Published online: 23 October 2014

(C) Springer Science+Business Media New York 2014

A number of philosophers attribute the underrepresentation of women in philosophy largely to bias against women or some kind of wrongful discrimination. They cite six sources of evidence to support their contention: (1) gender disparities that increase along the path from undergraduate student to full-time faculty member; (2) anecdotal accounts of discrimination in philosophy; (3) research on gender bias in the evaluation of manuscripts, grants, and curricula vitae in other academic disciplines; (4) psychological research on implicit bias; (5) psychological research on stereotype threat; and (6) the relatively small number of articles written from a feminist perspective in leading philosophy journals. (Due to space limitations in the print version of the article, sections (3), (4), and (5) are omitted here. The full version is available at www.nas.org/articles/women_in_philosophy_ problems_with_the_discrimination_hypothesis. We urge the interested reader to take a look at the integral version, because the missing sections constitute a very important part of our argument.)

In each case, we find that proponents of the discrimination hypothesis, who include distinguished philosophers in fields such as philosophy of science, metaphysics, and philosophy of language, have tended to present evidence selectively. Occasionally they have even presented as evidence what appears to be something more dubious-for example, studies supporting the

\footnotetext{
Neven Sesardic is professor of philosophy at Lingnan University, Tuen Mun, NT, Hong Kong; sesardic@In.edu.hk. He is the author of Making Sense of Heritability (Cambridge University Press, 2005).

Rafael De Clercq is associate professor and head of the Department of Visual Studies, and adjunct associate professor of philosophy, Lingnan University, Tuen Mun, NT, Hong Kong; rafaeldeclercq@ln.edu.hk.

The authors thank these individuals for useful comments on earlier drafts: Tomislav Bracanović, Stephen J. Ceci, Andrew Irvine, Paisley Livingston, Darrell Rowbottom, Nosson ben Ruvein, David N. Stamos, Matej Sušnik, Omri Tal, Daniel Wikler, Wendy M. Williams, and Jiji Zhang. None of these people, however, should be assumed to agree with the main claims of this paper.
} 
discrimination hypothesis based on data that have been reported "lost" under suspicious circumstances.

It is not the aim of this paper to settle the question of the causes of female underrepresentation in philosophy. Rather, we argue that, contrary to what many philosophers claim, the overall information available does not support the discrimination hypothesis.

\section{From Gender Disparity to Discrimination?}

The Canadian Philosophical Association passed the following recommendation at its Annual General Meeting in 1992: "In any decade in any department, at least fifty percent of new permanent or probationary positions should be filled by women." In some situations, new employments were even supposed to exceed the prescribed minimum quota of 50 percent women; an additional proviso stated that "if achieving [the set goal of] twenty-seven percent female faculty by 2000 requires a hiring rate for women that is higher than fifty percent, the higher rate should be implemented." ${ }^{2}$ The department of philosophy at the University of Toronto went further, setting a goal of hiring at least two-thirds women, and it even managed to exceed that quota in carrying out its five-year plan. ${ }^{3}$

In the report in which the Canadian Philosophical Association proposed these measures it is claimed that "there is compelling evidence that philosophy's gender imbalance is the source of bias and partiality in many of its theoretical products and that a better representation of women would help to rectify these shortcomings." "4 However, no reference was given to any source of the alleged "compelling evidence."

Obviously, in the absence of additional evidence, mere information about percentages is insufficient to prove "bias and partiality": the percentage of women among philosophy professors (or among the recent hires) being much lower than 50 percent does not, in itself, imply that there is a bias against women in the hiring process. It may even be that the process is actually biased against men.

In her 2008 article "Changing the Ideology and Culture of Philosophy: Not by Reason (Alone)," MIT professor of linguistics and philosophy Sally Haslanger

\footnotetext{
${ }^{1}$ B. Baker et al., Report to the Canadian Philosophical Association from the Committee to Study Hiring Policies Affecting Women (Ottawa, ON: Canadian Philosophical Association, 1991), 18.

${ }^{2} \mathrm{Ibid}$.

${ }^{3}$ L.W. Sumner, "Why the Numbers Count," Dialogue 35, no. 2 (1996): 375-85.

${ }^{4}$ Ibid., 16 .
} 
provides a table with percentages of women among the faculty of the top twenty graduate programs in philosophy in the U.S., ranging from 4 percent to 36 percent, and concludes that "the data mostly speak for themselves." But again, the data don't speak for themselves at all. Without additional information, it is impossible to draw any conclusion.

To establish even a prima facie case for anti-woman hiring bias, it would be necessary to first compare the percentage of women among the job applicants with the percentage of women among job recipients. Only if the latter percentage is lower than the former is there prima facie evidence for hiring discrimination against women.

University of British Columbia professor of philosophy Andrew Irvine compared exactly these percentages in the Canadian academic job market over a twenty-year period ending in $1996 .{ }^{6}$ According to his estimation, the percentage of female job recipients was on the whole higher than the percentage of female job applicants, which led him to conclude that "if systemic discrimination is occurring within contemporary university hiring, it is more likely to be occurring in favor of, rather than against, women."7

In 2002, Doreen Kimura, a Canadian psychologist and professor at Simon Fraser University, surveyed thirty-six schools and departments in total at two major Canadian universities and confirmed Irvine's finding: of the three most recent hires to fill positions in each school or department studied, women represented 29 percent of the total number of applicants, but 41 percent of all individuals hired. ${ }^{8}$

Trying to resolve the same issue, psychology professor Clive Seligman went over the data on academic hiring at the University of Western Ontario from 1991-1992 to 1998-1999, and reached this conclusion:

Over the 8 years, on average: $5.4 \%$ of female applicants were appointed compared to $2.9 \%$ of male applicants; $21.7 \%$ of female applicants were interviewed compared to $15 \%$ of male applicants; and $24.9 \%$ of female applicants who were interviewed were hired whereas $19.2 \%$ of men who were interviewed were appointed. Again, the results in each of the years are

\footnotetext{
${ }^{5}$ Sally Haslanger, "Changing the Ideology and Culture of Philosophy: Not by Reason (Alone)," Hypatia 23, no. 2 (Spring 2008): 214.

${ }^{6}$ Andrew D. Irvine, "Jack and Jill and Employment Equity," Dialogue 35 (1996): 255-92.

${ }^{7}$ Ibid., 261

${ }^{8}$ Doreen Kimura, "Preferential Hiring of Women," letter to the editor, UBC Reports, January 10, 2002, available at http://www.safs.ca/april2002/hiring.html.
} 
remarkably consistent. Women had almost twice the chance of being hired as did men. ${ }^{9}$

Similar results were obtained in a recent comprehensive study commissioned by the U.S. Congress to assess gender differences in the careers of science, engineering, and mathematics faculty-the area with the highest underrepresentation of women. ${ }^{10}$ Conducted under the auspices of the National Research Council, Gender Differences at Critical Transitions in the Careers of Science, Engineering, and Mathematics Faculty included two surveys of major research universities, focusing on almost five hundred departments and more than eighteen hundred faculty members.

The authors reported that among those interviewed for tenure-track or tenured positions, the percentage of women interviewed was higher than the percentage of women who applied for those positions, and that tenure-track women in all disciplines received a percentage of first offers that was greater than their overall percentage in the interview pool. ${ }^{11}$ The situation was the same with tenured positions in all disciplines except biology.

So we find a pattern according to which there are more women, percentage-wise, at a later stage than at an earlier stage throughout the hiring process - which is exactly the opposite of what one would expect if there were discrimination against women.

But why are there fewer women than men at the application stage in the first place? Could this be a result of discrimination? It could, but evidence is needed to support this hypothesis. Moreover, assuming that the situation is really so inhospitable for women in the academic job market, it would be odd if women were first discouraged from applying for academic jobs, only to be favored over men once they submit an application. There is room here for different explanations, including a theory that does not posit discrimination.

There are at least two different nondiscrimination scenarios in the literature that have been offered to account, at least in part, for the lower percentage of women in some academic fields: gender differences in abilities and gender differences in interests.

The first factor is a possible statistical difference between the sexes in the mental abilities that are of key importance for success in those fields. For

\footnotetext{
${ }^{9}$ Clive Seligman, "Summary of Recruitment Activity for All Full-Time Faculty at the University of Western Ontario by Sex and Year" (April 2001), http://www.safs.ca/april2001/recruitment.html; tables taken from Office of the Provost and Vice-President (Academic), Full-Time Faculty Distribution, Appointments, and Recruitment - by Gender (London, Ontario, Canada: University of Western Ontario, 2000), http://www.uwo. ca/western/facgend99/facgend.pdf.

${ }^{10}$ National Research Council, Gender Differences at Critical Transitions in the Careers of Science, Engineering, and Mathematics Faculty (Washington, DC: The National Academies Press, 2010).

${ }^{11}$ Ibid., 157.
} 
instance, a set of findings that has been replicated a number of times shows that "males score higher on some tasks that require transformations in visual-spatial working memory.... and fluid reasoning, especially in abstract mathematical and scientific domains." ${ }^{12}$ Several meta-analyses yield the conclusion that there are large gender differences in mental rotation and mechanical reasoning favoring males, "which some have suggested underlie sex differences in advanced math." " Furthermore, due to greater male variability there are proportionately more males than females at either tail of the distribution of abilities, which mathematically entails (assuming normal distribution) that the male/female ratio will rise ever more steeply as we move to the pool of people with higher and higher abilities. For example, among seventh graders scoring a perfect 800 in the mathematics component of the SAT between 2006 and 2010, there were 6.58 males for every female. ${ }^{14}$ The relevance of this statistical effect for our discussion is obvious, given that academics in exact sciences are recruited from those with exceptionally high mathematical abilities. It is also relevant for the situation in philosophy, because the underrepresentation of women seems to be most pronounced in the more technical areas of philosophy such as logic, decision theory, and philosophy of mathematics. ${ }^{15}$

The second nondiscrimination factor that might be responsible for the gender disparity in some academic fields is the male-female difference in interests. According to a recent meta-analysis of the relevant research, there is indeed a large difference between men and women along the things-people dimension, with men more interested in things-oriented careers, in contrast to women, who tend to prefer people-oriented careers. Also, "men generally showed more Realistic and Investigative interests as well as stronger interests in the STEM areas; in comparison, women tend to have more Artistic, Social, and Conventional interests and to express less interest in the STEM fields." 16 Other studies also report "very large differences in gender-related interests." And a similar claim about the male-female difference in interests is defended

\footnotetext{
${ }^{12}$ Robert J. Sternberg and Scott Barry Kaufman, The Cambridge Handbook of Intelligence (Cambridge and New York: Cambridge University Press, 2011), 254.

${ }^{13}$ Stephen J. Ceci, Wendy M. Williams, and Susan Barnett, "Women's Underrepresentation in Science: Sociocultural and Biological Considerations," Psychological Bulletin 135, no. 2 (2009): 220.

${ }^{14}$ Stephen J. Ceci and Wendy M. Williams, "Sex Differences in Math-Intensive Fields," Current Directions in Psychological Science 19, no. 5 (2010): 276.

${ }^{15}$ Sally Haslanger, "Preliminary Report of the Survey on Publishing in Philosophy," APA Newsletter on Feminism and Philosophy 10 (2010): 11.

${ }^{16}$ Rong Su, James Rounds, and Patrick Ian Armstrong, "Men and Things, Women and People: A MetaAnalysis of Sex Differences in Interests," Psychological Bulletin 135, no. 6 (2009): 871.

${ }^{17}$ See, for example, Richard A. Lippa, "Sex Differences in Personality Traits and Gender-Related Occupational Preferences Across 53 Nations," Archives of Sexual Behavior 39, no. 3 (June 2010): 619.
} 
by Simon Baron-Cohen, professor of developmental psychopathology at the University of Cambridge and fellow of Trinity College, in The Essential Difference: The Truth about the Male and Female Brain. ${ }^{18}$

We don't want to commit ourselves to defending any of the alternative potential explanations of the gender gap that are the subject of scholarly study at present. Our aim is solely to urge the reader to resist the call to accept the discrimination hypothesis without evaluating the totality of evidence bearing on this complex question.

To see how the mere numerical fact of gender disparity — unaccompanied by any understanding of the larger context — can move prominent philosophers to rush to a conclusion and galvanize them into urgent action unjustified by the facts, consider the following sequence of events. On June 19, 2013, Kieran Healy, a Duke University associate professor of sociology, published data on his blog showing that out of all recent citations in four prestigious philosophy journals, female authors comprise just 3.6 percent of the total. ${ }^{19}$ Although Healy warned that "this is exploratory work" and that there are unanswered "questions about the underlying causes of any patterns that show up in the data" as well as "various comparisons that sound straightforward...but are actually quite complicated to answer properly, or imply a lot more data collection and analysis than I can do here," Edward Zalta and Uri Nodelman, the primary editors of the Stanford Encyclopedia of Philosophy (SEP), soon learned about Healy's data and decided the issue needed immediate attention. On July 12, Zalta and Nodelman sent an email with the subject "SEP request concerning citations" to all SEP authors, subject editors, and referees. The email included a link to Healy's data and informed SEP collaborators that the editors take the issue of "undercitation" of women philosophers seriously. Although Zalta and Nodelman neither explained why the issue is so pressing nor clarified their objective (besides pushing some numbers up), they "encourage[d] our authors, subject editors, and referees to help ensure that SEP entries do not overlook the work of women or indeed of members of underrepresented groups more generally." Furthermore, they urged collaborators to write to the editor "any time [they] notice a source missing from an SEP entry (whether or not it is [your] own entry)."

There are five problems here. One, Zalta and Nodelman seem to assume, without providing any evidence, that the "undercitation" of women is at least partly the result of bias, i.e., the tendency of philosophers to "overlook"

\footnotetext{
${ }^{18}$ Simon Baron-Cohen, The Essential Difference: The Truth about the Male and Female Brain (New York: Basic Books, 2003).

${ }^{19}$ Kieran Healy, "Lewis and the Women," KieranHealy.org (blog), June 19, 2013, http://kieranhealy.org/blog/ archives/2013/06/19/lewis-and-the-women/.
} 
women's publications more often than men's. Two, the way Zalta and Nodelman try to address this undercitation resembles an attempt to cure a disease without knowing its cause. Three, their action will have a perverse effect: de facto nudging many scholars to cite more female philosophers - and to report on those who fall behind in this task - may distort genuine citation patterns in the discipline and undermine the integrity of a bibliometric analysis of philosophical publications. Four, there might be another perverse effect: If SEP's initiative to boost the citation of women's publications becomes more widely adopted within philosophy, then philosophers who do not believe that the "undercitation" is due to sexist bias might react by correcting for what they perceive as citation inflation for a select group. As a consequence, these philosophers might start to interpret the number of citations of female philosophers as being, on average, a less reliable sign of scholarly quality than the number of citations of male philosophers. And five, it should be expected that other demographic groups would soon follow suit and demand that their "unfairly" low citation rate be similarly augmented.

\section{Anecdotal Evidence}

Sally Haslanger claims there was "a lot of outright discrimination" when she was a student, and that "blatant discrimination has not disappeared." ${ }^{20}$ As evidence of discrimination, Haslanger cites, for example, "occasions when a woman's status in graduate school was questioned because she was married, or had a child (or had taken time off to have a child so was returning to philosophy as a 'mature' student), or was in a long-distance relationship"; and "many women who have interests and talents in metaphysics and epistemology who have been encouraged to do ethics or history of philosophy."21

Needless to say, it is not our intention to deny that instances of discrimination against women in philosophy occur. For all we know, there is occasional discrimination against individuals belonging to all sorts of groups, including conservative philosophers, philosophers with a degree from less prestigious institutions, philosophers working in "marginal" areas, philosophers who are not native speakers of English, etc. After all, there is evidence pointing to discrimination against men as well (see above), although this phenomenon is rarely discussed.

\footnotetext{
${ }^{20}$ Haslanger, "Changing the Ideology," 211.

${ }^{21}$ Ibid.
} 
What we want to question is whether this sort of anecdotal evidence supports the view that discrimination against women in philosophy is pervasive and systematic. Haslanger writes that philosophy departments "mostly" do not provide "a good working environment with mutual respect" and that "it is very hard to find a place in philosophy that isn't actively hostile toward women and minorities, or at least assumes that a successful philosopher should look and act like a (traditional, white) man."22 Similarly, University of Massachusetts, Amherst, professor of philosophy Louise Antony asserts that "the discipline of philosophy marks the site of a unique convergence, intensification, and interaction of discriminatory forces." 23

In the evaluation of these claims, how much weight should be assigned to subjective impressions and charges, often anonymously made against unidentified male philosophers? For example, how much weight should be assigned to the reports about "men behaving badly" in philosophy found on the What Is It Like to Be a Woman in Philosophy? website, ${ }^{24}$ which is cited as a source of evidence by Helen Beebee and Jenny Saul, of the University of Manchester and the University of Sheffield, respectively, among other scholars? ${ }^{25}$

First of all, there is an obvious danger of a self-selection effect here. The website declares its agenda "to do something about the situation of women in philosophy," which obviously presupposes that the situation is bad and that a pressing need to change it exists. Therefore, people with negative experiences will be more likely to share their stories than those who see or encounter no major problems and who, consequently, have little or nothing of significance to report. This will tend to create a distorted picture of the position of women in philosophy, in the same way that a website entitled "What Is It Like to Be a Conservative in Philosophy?" probably would.

Another problematic aspect is the proclaimed policy of What Is It Like to Be a Woman in Philosophy? that "any negative stories should be told without any identifying information." ${ }^{, 2}$ Potential contributors are instructed: "Please

\footnotetext{
${ }^{22}$ Ibid., 212.

${ }^{23}$ Louise Antony, “Different Voices or Perfect Storm: Why Are There So Few Women in Philosophy?” Journal of Social Philosophy 43, no. 3 (September 2012): 233.

${ }^{24}$ What Is It Like to Be a Woman in Philosophy? http://beingawomaninphilosophy.wordpress.com.

${ }^{25}$ See Helen Beebee and Jenny Saul, Women in Philosophy in the UK: A Report by the British Philosophical Association and the Society for Women in Philosophy UK (British Philosophical Association and Society for Women in Philosophy UK, 2011), http://www.bpa.ac.uk/uploads/2011/02/BPA_Report_Women_In_ Philosophy.pdf; Helen Beebee, "Women and Deviance in Philosophy," in Women in Philosophy: What Needs to Change? ed. Katherine Hutchison and Fiona Jenkins (Oxford and New York: Oxford University Press, 2013), 61-80; and Jennifer Saul, "Implicit Bias, Stereotype Threat and Women in Philosophy," in Hutchison and Jenkins, Women in Philosophy, 39-60.

${ }^{26}$ What Is It Like to Be a Woman in Philosophy? About, "Our Policies," http://beingawomaninphilosophy. wordpress.com/our-policies-2/.
} 
anonymise your story as far as possible, especially if it is negative." ${ }^{27}$ This does not exactly inspire confidence in the truthfulness of the stories submitted, or the potential for verifying their accuracy. Therefore, increased caution is advised, especially because, thus far, those who run the website have said nothing about whether - or how - they try to corroborate the reports they receive from readers. An additional worry is that in one case (known to us), the submission of a completely fabricated story was promptly published on What Is It Like to Be a Woman in Philosophy?-apparently without any independent verification.

It is rarely mentioned that the goal of greater numbers of women in philosophy as a profession can be undermined if the situation is systematically represented as being far worse than it really is. Many of the women who have talent and a strong interest in philosophy are likely to get cold feet if they hear prominent philosophers expressing their rage about how poorly women have been treated in their discipline, which is alleged to be riddled with discrimination, sexism, and bigotry. If a potential philosophy scholar swallows these horror stories (and why shouldn't she?), pursuing the love of wisdom would hardly remain her first career choice.

If we are right, however, that this dark picture of philosophy has not been confirmed by the facts, then exaggerated, repeated, and unchallenged claims about bias against women in philosophy will probably result in many intelligent and able young women avoiding any encounter with what they will see, unjustifiably, as an academic slum of irrationality and hatefulness.

\section{Is There Too Little Feminism in Philosophy?}

In her widely cited article discussed above, "Changing the Ideology and Culture of Philosophy: Not by Reason (Alone)," Haslanger writes:

[I]t is appalling to me that there is so little feminist work published in the [seven leading philosophical] journals examined, even in journals focused on ethics and political philosophy....Given the numbers of women philosophers working on feminism, this is striking. Jennifer Saul has told me that she sees a pronounced difference in the responses she gets from journals to her work in philosophy of language compared to her feminist work. Her papers in philosophy of language are always sent out to referees; her feminist submissions, however, are

\footnotetext{
${ }^{27}$ What Is It Like to Be a Woman in Philosophy? Send a Story, http://beingawomaninphilosophy.wordpress. com/send-a-story- $2 /$.
} 
routinely sent back without having been considered by a reviewer. What is going on here ${ }^{28}$

There are all kinds of things that might be going on here. But given what we know, and especially what we do not know, it seems definitely premature to be "appalled" at the situation. Contrary to what Haslanger writes, the journal data are not a sign "that something is wrong." "9 Without further information, the journal data that she cites are not a sign of anything.

Similarly, the fact that a philosopher has different success rates in publishing her work in different philosophical areas is not in itself evidence of bias against the area in which she is less successful. With so many unknowns, any such inference would be unjustified.

Nevertheless, it is again merely on the basis of Haslanger's journal data that it is claimed in "Women in Philosophy," a document posted on the website of the School of Philosophy at the Australian National University that "the incredibly low percentage [2.36 percent] of feminist philosophy articles published in leading philosophy journals" suggests that "feminist questions are side-lined in the philosophy discipline." 30

Is it really true that feminist questions are sidelined in philosophy? If yes, one would expect that the words "feminism" and "feminist" would rarely appear in philosophy catalogues of leading publishers or in major philosophical encyclopedias. But an online review of the titles published by Oxford University Press in recent years reveals that more volumes appeared in the Oxford Studies in Feminist Philosophy series than in three other series combined that represent traditional central areas of philosophy, namely, Oxford Studies in Metaphysics, Oxford Studies in Epistemology, and Oxford Studies in the Philosophy of Science. Similarly, the following table compares frequency of appearance of different terms ending in "ism" in the ten-volume Routledge Encyclopedia of Philosophy: ${ }^{31}$

\footnotetext{
${ }^{28}$ Haslanger, "Changing the Ideology," 215.

${ }^{29}$ Ibid., 216.

30“"Women in Philosophy," Australian National University, School of Philosophy, http://philrsss.anu.edu.au/ special-events/women-philosophy); this document is no longer publicly accessible, but the interested reader may find it at https://dl.dropboxusercontent.com/u/50501346/ANU.webarchive.

${ }^{31}$ Routledge Encyclopedia of Philosophy (London and New York: Routledge, 1998).
} 
Table 1

"Isms" in Routledge Encyclopedia of Philosophy Frequency of Appearance

\begin{tabular}{lc}
\hline Term & Number of Times Used \\
\hline \hline Feminism, feminist & 1303 \\
Empiricism, empiricist & 1193 \\
Materialism, materialist & 1220 \\
Idealism, idealist & 1542 \\
Rationalism, rationalist & 972 \\
Naturalism, naturalist & 1185 \\
\hline
\end{tabular}

These numbers indicate that, in terms of attention received in the philosophical community feminism is faring quite well, especially keeping in mind that it is relatively new to the philosophical scene.

How often do these various "isms" appear in titles of articles listed in the Stanford Encyclopedia of Philosophy, an up-to-date reference work maintained online ${ }^{32}$ Here are the data:

Table 2

"Isms" Found in Article Titles

Stanford Encyclopedia of Philosophy

\begin{tabular}{lc}
\hline Term & Number of Times Used \\
\hline \hline Feminism, feminist & 36 \\
Empiricism, empiricist & 1 \\
Materialism, materialist & 1 \\
Idealism, idealist & 0 \\
Rationalism, rationalist & 1 \\
Naturalism, naturalist & 5 \\
\hline
\end{tabular}

The number of SEP articles that contain "feminism" (or "feminist") in the title is more than four times higher than the number of all articles combined whose titles mention empiricism, materialism, idealism, rationalism, or naturalism.

These numbers suggest that, far from sidelining feminism, philosophers make extra efforts to dedicate an inordinate amount of space to feminism, and precisely in those all-important publications that are focused on presenting the state of the art in philosophy to its practitioners as well as to the wider public.

It is hard to reconcile these signs of a sympathetic disciplinary attitude toward feminism, which is manifested in many other ways, too, with the hypothesis of a massive sexist, antifeminist stance coming from basically the same people —only now in their role as journal editors and referees. Of course, the hypothesis might

\footnotetext{
${ }^{32}$ Stanford Encyclopedia of Philosophy, http://plato.stanford.edu/index.html.
} 
still be true, but to be taken seriously much more is needed than the bare assertion that the percentage of feminist articles on philosophy accepted is "incredibly low."

There are many reasons why different areas of philosophy are represented in different proportions in the discipline's top journals, the most common being that philosophers in the "under-published" subdisciplines simply have not managed to come up with ideas that would generate sufficient interest and excitement among other philosophers. As long as this kind of "internal" explanation is left unexplored and is not shown to be implausible, it seems inappropriate to attribute massive prejudice to our colleagues - especially if this charge is based solely on the claim that the actual share of journal space allotted to a certain area is much lower than an unspecified approximate quota to which it is supposedly entitled.

A quite radical proposal on this issue has been recently brought forward in a newsletter of the American Philosophical Association (APA):

Why not a more proactive stance, one that ties adequacy of reviewing procedures to the value a journal places on feminist philosophy - which is one measure of the value it places on women. ${ }^{33}$

According to this proposal, then, any journal not publishing enough feminist philosophy would immediately fall under suspicion of having inadequate reviewing procedures and a sexist attitude.

But in fact a low opinion of feminism is not in itself a sign of sexism. And yet we can also read (again, in an APA newsletter):

If one is interested in eliminating sexism from the philosophical profession, one must take feminist philosophy seriously. ${ }^{34}$

By contraposition, this statement actually says that anyone who doesn't take feminism seriously is not interested in eliminating sexism from philosophy. As long as "feminism" refers to a substantive philosophical claim (however interpreted) and does not degenerate into a theoretically uninteresting moral truism (e.g., "Don't treat women unfairly!"), the statement above is manifestly false. You can strongly disagree with feminism (however construed), even to the point of thinking that it should not be taken seriously (as a philosophical claim),

\footnotetext{
${ }^{33}$ Janet A. Kourany, "How Do Women Fare in Philosophy Journals? An Introduction," APA Newsletter on Feminism and Philosophy 10, no. 1 (Fall 2010): 5, http://c.ymcdn.com/sites/www.apaonline.org/resource/ collection/D03EBDAB-82D7-4B28-B897-C050FDC1ACB4/v10n1Feminism.pdf.

${ }^{34}$ Erin C. Tarver, "The Dismissal of Feminist Philosophy and Hostility to Women in the Profession," APA Newsletter on Feminism and Philosophy 12, no. 2 (Spring 2013): 8.
} 
but your negative attitude toward feminism does not thereby entail that you condone sexism.

Directly linking antifeminism to sexism may give feminists a powerful rhetorical and political weapon against their opponents, but it will not earn them professional respect. It is also probably among the factors that contribute to fomenting a confrontational atmosphere in which feminists are not always able to take criticisms in stride.

To give just one example, in a recent interview Elizabeth Anderson, Arthur F. Thurnau Professor and John Dewey Distinguished University Professor of Philosophy and Women's Studies at the University of Michigan and a leading contemporary feminist, had this to say about several very prominent philosophers who, in their own ways, have tried to explain in great detail why they strongly disagree with the feminist position:

[It is striking] how detached they are from academic norms of rational discourse....There is a level of obtuseness and hysteria here that is quite shocking. It's like trying to engage people who claim that Obama is a Muslim jihadist terrorist. ${ }^{35}$

Among the critics of feminism who are characterized in this manner are Noretta Koertge and Susan Haack, scholars held in very high esteem in philosophy. Needless to say, the suggestion that their opposition to feminism is similar to "the claim that Obama is a Muslim jihadist terrorist" is ludicrous.

\section{Conclusion}

In a recent court case Loretta Preska, Chief Judge of the U.S. District Court for the Southern District of New York, dismissed a complaint about sex discrimination by saying: '“J'accuse!' is not enough in court. Evidence is required. ${ }^{36}$ We should expect nothing less in philosophy.

We have examined the main arguments for the claim that there is widespread discrimination against women in philosophy. We have tried to show that these arguments, individually and collectively, fall far short of establishing that conclusion.

\footnotetext{
${ }^{35}$ Elizabeth Anderson, “The New Leveller," interview by Richard Marshall, 3:AM Magazine, July 25, 2012, www.3ammagazine.com/3am/the-new-leveller.

${ }^{36}$ EEOC v. Bloomberg L. P., 07 Civ. 8383(LAP), NYLJ 1202618858451, at *1 (SDNY, Decided September 9, 2013), www.nysd.uscourts.gov/cases/show.php?db=special\&id=124.
} 